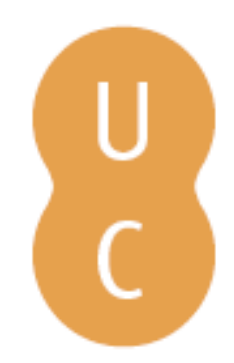

\title{
nommalina
}

\section{Predictive maintenance!: to do or let die}

Autor(es): $\quad$ Dias, Pedro; Farinha, José Torres; Fonseca, Inácio; Cunha, Jorge

Publicado por: $\begin{aligned} & \text { Imprensa da Universidade de Coimbra; Faculdade de Ciências e } \\ & \text { Tecnologia da Universidade de Coimbra, Departamento de Engenharia } \\ & \text { Mecânica }\end{aligned}$

URL $\quad$ URI:http://hdl.handle.net/10316.2/33315

DOI: $\quad$ DOI:http://dx.doi.org/10.14195/978-972-8954-42-0_6

Accessed : $\quad$ 26-Apr-2023 05:02:32

A navegação consulta e descarregamento dos títulos inseridos nas Bibliotecas Digitais UC Digitalis, UC Pombalina e UC Impactum, pressupõem a aceitação plena e sem reservas dos Termos e Condições de Uso destas Bibliotecas Digitais, disponíveis em https://digitalis.uc.pt/pt-pt/termos.

Conforme exposto nos referidos Termos e Condições de Uso, o descarregamento de títulos de acesso restrito requer uma licença válida de autorização devendo o utilizador aceder ao(s) documento(s) a partir de um endereço de IP da instituição detentora da supramencionada licença.

Ao utilizador é apenas permitido o descarregamento para uso pessoal, pelo que o emprego do(s) título(s) descarregado(s) para outro fim, designadamente comercial, carece de autorização do respetivo autor ou editor da obra.

Na medida em que todas as obras da UC Digitalis se encontram protegidas pelo Código do Direito de Autor e Direitos Conexos e demais legislação aplicável, toda a cópia, parcial ou total, deste documento, nos casos em que é legalmente admitida, deverá conter ou fazer-se acompanhar por este aviso.

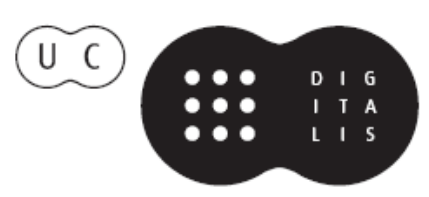




\title{
Predictive Maintenance! To do or let Die
}

\author{
Pedro Dias ${ }^{1}$, José Torres Farinha ${ }^{2}$, Inácio Fonseca ${ }^{3}$, Jorge Cunha ${ }^{4}$ \\ pedro.dias@skf.com1; torres.farinha@dem.uc.pt2; inacio.fonseca@dem.uc.pt3; jorge.cunha@skf.com4 \\ SKF Portugal1,4; CEMUC2,3 \\ PORTUGAL1,2,3,4
}

\begin{abstract}
In a competitive world all equipment must maximize its availability. The predictive maintenance objective is to follow the evolution of its use and the tear that results from the dynamics of components.

Nowadays, with the evolution of technology it is possible to check and detect almost every problem. In critical organizations, like paper industry, chemical industry, oil industry, and so on, it is necessary to follow the "health" of the most part of equipment in general, and the vital ones in particular, because even small errors can cause a lot of monetary damages.
\end{abstract}

This type of companies need to check every detail of their assets. The majority of the companies use a lot of technology to evaluate the condition of each critical component. They want to know the value of on-condition variables like vibration monitoring offline, vibration monitoring online, thermograph, oil analysis, and so on.

However, having lot of offers of equipment for diagnosis and a lot of offers of maintenance services by specialized companies, the factories didn't increase the predictive maintenance level because they aren't sensitive enough to do that. The pressure that the international economic market has in companies causes factories to work every minute they can before equipment and components break. Companies try to delay the time of each maintenance intervention, but this delay, when it is done without on-condition accompaniment increases the total maintenance costs, which increases the total value of equipment maintenance, both direct and indirect. In this case, the predictive maintenance can have an important role to increase the production time.

These are the main topics that will be handled in the paper industry, with focus on vibration monitoring applied in a paper factory, including maintenance analysis versus cost analysis.

Keywords - on-condition maintenance; predictive maintenance; vibration analysis; paper industry.

\section{INTRODUCTION}

The pulp and paper mills work with top market machine. A lot of brands are specialized in a part of the process. For example, the pumps of the pulp and paper plant have the same features as the fluid in its movement, corresponds a real situation where some manufacturers have gained a lot of expertise in it.

For this work, the manufacturers design the machine components to work $24 \mathrm{~h}$ a day, during a specific time where the reliability is maintained high enough. This time, also called safety time, corresponds to which the manufacturer indicates to begin the maintenance schedule; in other words, to start the process of changing some components of the machine according to a relation working time/scheduled maintenance this maintenance type is also called Preventive Maintenance.

Preventive Maintenance gives an important contribution to safety. The company follows up every advice of the manufacturer and changes every component of the machine according to the work times stabilized by the manufacturer. In this type of maintenance there are a lot of pieces that are changed after they work a well defined number manufacturing hours. If we put these pieces in the scrap, we lose a lot of money.

In the ambit of the precedent context this paper deals with a tool that SKF has developed to solve that type of problems and also improve the maintenance tasks in the factory, helping to increase the operation of all equipments and, by consequence, to increase the production.

\section{THE COMPANY}

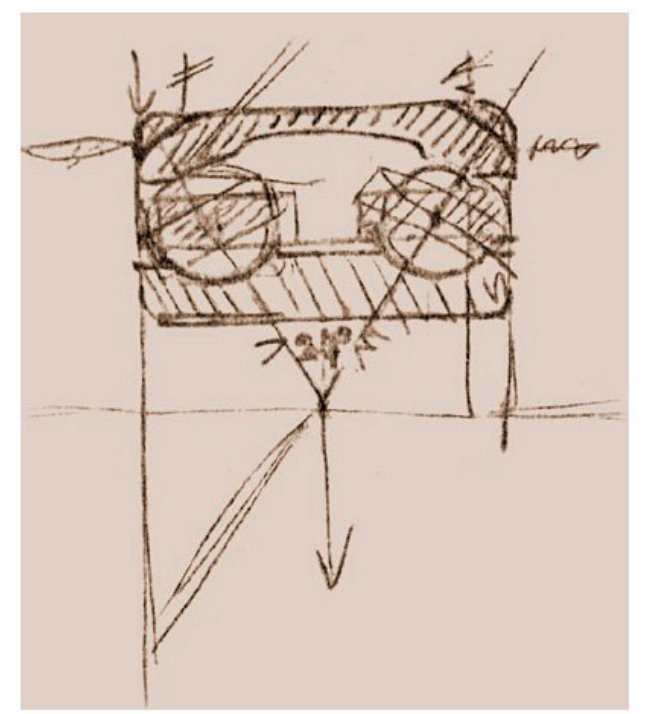

Fig. 1 - Drawing of multi-row self-aligning radial ball bearing

SKF is a company more than 100 years old. The company has been a leading global technology provider since 1907. It began with the production of bearings leaded by Mr. Sven Wingqvist who, in that year, registered the patent $\mathrm{n}^{\circ} 25406$, for a multi-row self-aligning radial ball bearing (Figure 1). With 
this discovery, this man found the solution for rigid ball bearing, [1-2].

Since this date, the company has been growing, opening their business in other areas like condition monitoring, seals, lubrication, etc.

Nowadays, SKF is based in five platforms, figure 2. These platforms we going talk in the platform "Services". In this platform they are included all systems and technology to monitor and manage the maintenance.

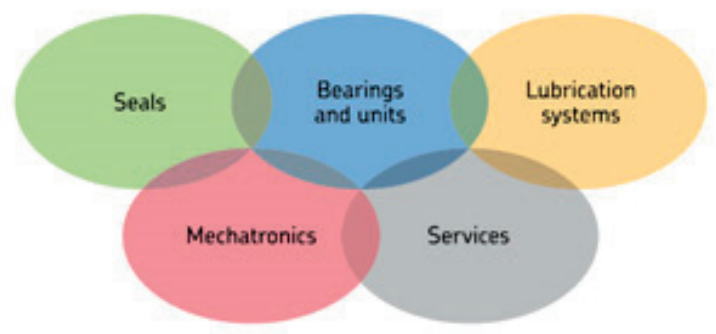

Fig. 2 - The 5 platforms which is based of the SKF business

\section{TECHNOLOGIES APPLIED TO PREVENTIVE MAINTENANCE OF PULP AND PAPER MACHINE}

At the beginning of the industrial paper era, when a lot of paper companies bought their first machines, they also acquired equipment to measure the vibration online. Due to the hard condition to work in the drier, this is the only way to analyze the bearings and the other components condition.

By the other hand, some pulp and paper plants strategy is to have outsourcing specialize partnerships to provide this specified service. To follow up both condition systems, the online and the offline measurement, there are partners specialize in the failures beginning detection as SKF. But this technology isn't the only one; there are complimentary variables to increase the diagnosis security like oil analysis among others.

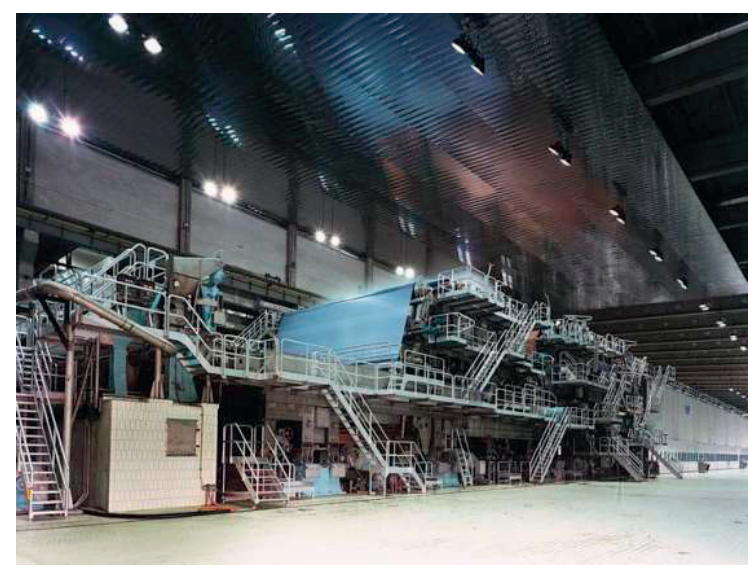

Fig. 3 - Paper Machine

In Figure 3, it can be seen a paper machine. The system online for vibration measurement collects the information about the several rolls bearing condition. In Figure 4 it can be seen the SKF system to follow up the status of dynamic components. This system is IMx-S of 32 channels that can measure 32 points of the paper machine or equipment that are considered critical.

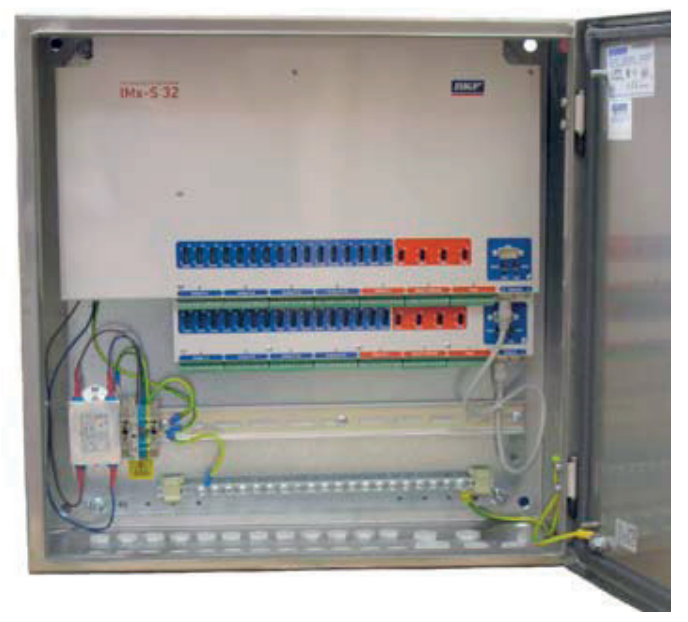

Fig. 4 - System SKF IMx'S

IMx-S is part of the SKF Multilog On-line System product range; it is designed to be used for a variety of condition monitoring applications. In conjunction with SKF@ptitude Observer or Analyst software, IMx-S provides a complete system for early fault detection and prevention, automatic advice for correcting existing or impending conditions and advanced condition-based maintenance to improve machine reliability, availability and performance, [2].

This system doesn't replace the old system of maintenance managing strategy. In other words, this technology doesn't replace the first level preventive maintenance. But it is a huge help in the work preparation, because it is possible to detect the flaws since the beginning.

The standard preventive maintenance is done by operators. It is necessary to approach the operators with the equipment. When the operator does this type of maintenance, he only looks for any visual problems (for example, an oil leakage), abnormal noise, etc. Every point that the operator sees is registered in a document that constitutes an historic concerning the problems throughout the time.

Every week the operators have a new route to do. Throughout the time, the company creates a historic of machine problems, and with this information it is possible to create a data base with critical value for some points of measurement, for example, the temperature.

\section{OPERATOR DRIVEN RELIABILITY (ODR) CONCEPT}

With new maintenance methodologies like TPM (Total Productive Maintenance), RCM (Reliability Centered Maintenance), LEAN Maintenance) each time more present in factories, the SKF company developed a system that can change the old preventive of on-condition maintenance 
techniques and increase the participation of operator in maintenance interventions, [3-4].

The term Operator Driven Reliability (ODR) relates to maintenance practices that are owned, managed, and performed by operators. Process operators usually have at least some interface with maintenance in so far as they will typically request maintenance support to investigate and correct suspect conditions that they have detected (usually by subjective way). Operators also become involved in maintenance through their participation in reliability-related activities namely the ones that are the Root Cause Failure Analysis (RCFA) or maintenance strategy review processes. A prime objective of the operator involvement in maintenance is the improvement of equipment support strategy. Their involvement ensures that operations staff understands and fulfill their role ensuring plant-wide reliability.

Accomplishing the complexity of modern production machinery, it is necessary that every department of factory works as a team. Only in this way it is possible to solve the problems and find the best solutions so that the faults don't happen again. Only with this condition, the company can reduce the production cost and increase the competitive edge.

To implement the ODR, it is necessary that the operator knows what to do and what he can do to improve. First, it is necessary to find the venue of the factory to implement this approach and then choose the best person to start. know:

The operators involved in this maintenance activity need to

- What constitutes a problem through equipment knowledge and performance standards;

- What to do when each problem is observed;

- What not to do when each problem is observed;

- What tasks fall within the limits of personal competence;

- What tasks are outside the limits of personal competence.

It can be given responsibility to the operator to help that each machine works according to the best performance and the condition from which it was designed.

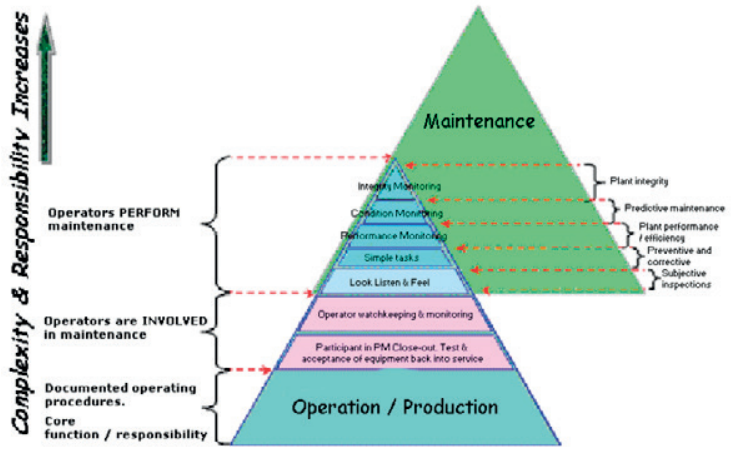

Fig. 5 - The increase of competence of the operator

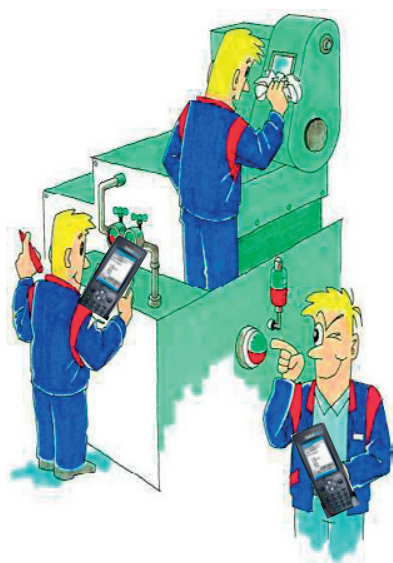

Fig. 6 - Operator check machine

In Figure 5, it is possible to see where the operator fits in the maintenance structure for this process.

The operator role is to go to the machine, follow the check list (this check list is prepared by maintenance and production) and put $\mathrm{OK}$ or not OK. To do that, the operator takes a portable PDA (Personal Digital Assistant) to register the status of the machine. In Figure 6, it is possible to observe this example. The operator checks the level of oil and cleans the glass and checks the valves.

\section{ODR PRINCIPLE OF FUNCTIONING}

Operator Driven Reliability (ODR) is a process pioneered by SKF that empowers operators to contribute proactively to a company-wide maintenance strategy. The process is built on a simple realization: equipment operators are usually the first to detect even the smallest changes in machine conditions. SKF operator involvement starts from the first ODR project facilitation meeting where operators participate in criticality and FMEA analysis. The shared asset knowledge is the basis for correct operator activities.

In first place, it is necessary to define the equipments that will be checked by ODR. With this list, it will do the routes (it is necessary to take attention to track, for the operator to make a circuit). At the next step, the points to check are defined and, if it is the case, the vibration points to measure. With every point characterized, it only needs to upload the routes in PDA software. When operator starts route, he switches on PDA and follows the instructions applied to each equipment registering all values. When one measurement is out of the normal value, the operator asks for help to solve the problem, [5].

Why did choose ODR to help improving this maintenance practice?

- Because this system can measure more points, can change the check list from paper to PDA (the problem with the paper is the risk of loss and the time necessary to insert data into system) what makes easier uploading data and quicker analyses about faults and so on. 


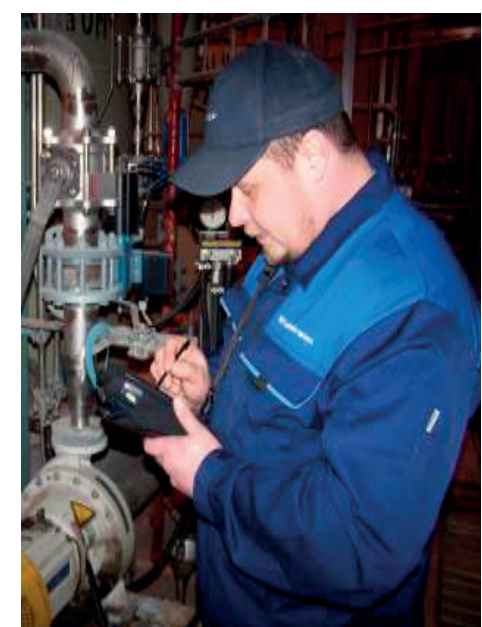

Fig. 7 - The operators makes an ODR route

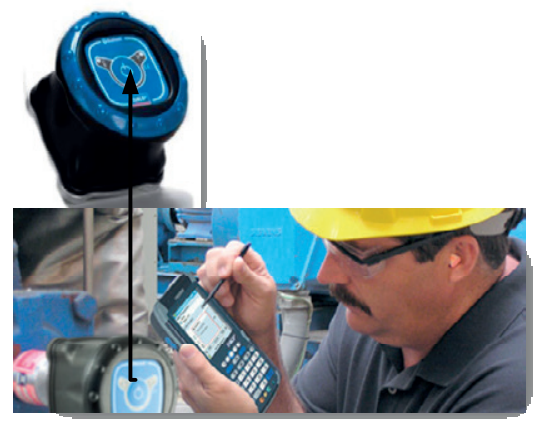

Fig. 8 - The operators makes an ODR route

In Figure 7 it is possible to see an operator analyzing and registering data on a PDA - in this case the operator only checks the level. However, for example, in the Figure 8, another operator is measuring a vibration in a machine. This is a great evolution by preventive maintenance versus maintenance through ODR. With this analysis, it is possible to detect a problem, and call the responsible of maintenance or the vibration technician to analyze in more detail the equipment and to detect the element damaged or what is inducing the increase of vibration values.

\section{ODR VALUE-ADDED}

As can be seen in Figure 9, through ODR it is possible to join the preventive maintenance with a first analysis of vibrations. It is also possible to upload the data to program and analyze the trends of all inspections. In the case of increasing of the value in one trend, the operator will solve the problem (for example, during a process fault) or may ask for help to a SKF technician or find the solution together in a team perspective. With this, the operator contributes with:

- Operator inspections provide increased opportunities for failure detection;
- Trending the inspection results that identifies small incremental changes;

- Sharing the results improves teamwork and proactive decision making.

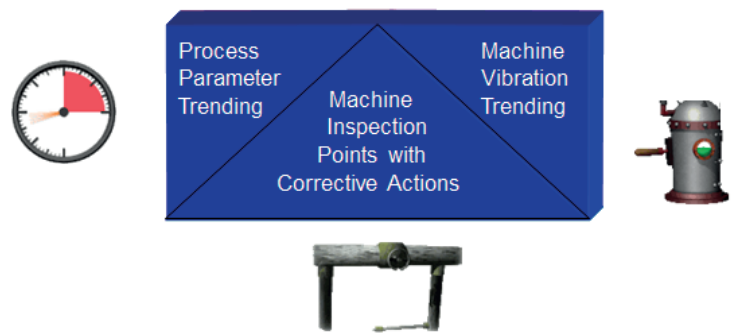

Fig. 9 - The Best Solution by SKF

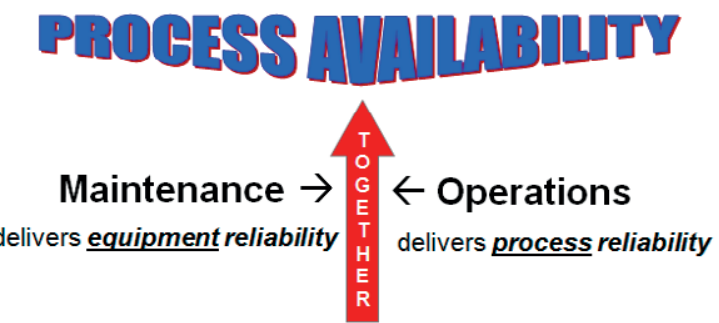

Fig. 10 - The Combination between Maintenance and Operation

The ODR makes the Maintenance and Operation work together and, as showed in Figure 10, when these two departments of the factory work together, it is possible to increase the workability of equipment and return all the potential of each equipment.

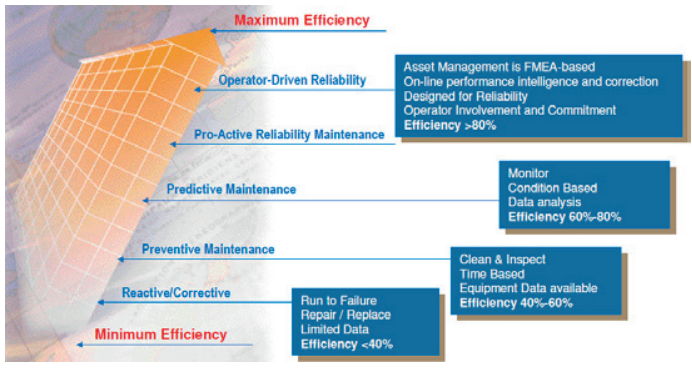

Fig. 11 - The Efficiency of ODR

This maximum efficiency, as we can see in Figure 11, is possible by the work of both partners. With the insertion of operators in maintenance work and decision, it will become a better environment to all the operators and essentially an easier communication between these two departments.

\section{CONCLUSIONS}

At the outset of this discussion, ODR was described as a logical extension of operator involvement in maintenance and the performance by operations staff of basic maintenance activities. It is difficult to imagine any production or processing plant without some element of operator involvement in maintenance. They invariably request maintenance work, and 
(though sometimes reluctantly) make equipment available for required maintenance. However, too often, this dialogue is unidirectional - this is the classic syndrome "we run it, you fix it".

However, experience shows that ODR is beneficial in terms of its cost effectiveness and development of an enlightened and productive dialogue between maintenance and production functions. Embracing an ODR approach diminishes maintenance time allowing to implement new monitoring and diagnostic technologies, without taking the risk of neglecting basic maintenance tasks.

\section{REFERENCES}

[1] SKF (2014): WWW.SKF.COM. 2014.06.21.

[2] SKF (2014): http://investors.skf.com/annual2010en/1-about-skf/SKFsplatforms.php auth. SKF. 20.06.2014.

[3] SKF Reliability Systems (2011): SKF Multilog On-line System IMx-S User Manual. Lulea.

[4] McKenna, T.; Oliverson, R. (1997): Glossary of reliability and maintenance terms. Houston: Gulf Publishing Company.

[5] SKF Reliability Systems @ptitudeXchange (2004): Operator Driven Reliability (ODR). The Definition, Scope, Limitations, Benefits, \& Positioning of ODR in the Maintenance World. - San Diego. 